\title{
Iminophosphine-palladium(0) complexes as highly active catalysts in the Suzuki reaction. Synthesis of undecaaryl substituted corroles
}

\author{
Alberto Scrivanti, ${ }^{\mathrm{a}, *}$ Valentina Beghetto, ${ }^{\mathrm{a}}$ Ugo Matteoli, ${ }^{\mathrm{a}}$ Simonetta Antonaroli, \\ Alessia Marini, ${ }^{\mathrm{b}}$ Federica Mandoj, ${ }^{\mathrm{b}}$ Roberto Paolesse ${ }^{\mathrm{b}}$ and Bruno Crociani ${ }^{\mathrm{b}, *}$ \\ a Dipartimento di Chimica, Università 'Cà Foscari' di Venezia, Calle Larga S. Marta 2137, 30123 Venezia, Italy \\ bipartimento di Scienze e Tecnologie Chimiche, Università di Roma 'Tor Vergata', 00173 Roma, Italy
}

Received 5 May 2004; revised 27 May 2004; accepted 28 May 2004

Available online 19 June 2004

\begin{abstract}
The iminophosphine-palladium $(0)$ complex $[\mathrm{Pd}(\mathrm{dmfu})(\mathrm{P}-\mathrm{N})] \quad\left[\mathrm{dmfu}=\right.$ dimethyl fumarate; $\mathrm{P}-\mathrm{N}=2-\left(\mathrm{PPh}_{2}\right) \mathrm{C}_{6} \mathrm{H}_{4}-1-$ $\left.\mathrm{CH}=\mathrm{NC}_{6} \mathrm{H}_{4}-4-\mathrm{OMe}\right]$ is a very efficient catalyst for the Suzuki coupling. In the reaction of aryl bromides with phenylboronic acid, turnover numbers up to ca. 200,000 are obtained at $110^{\circ} \mathrm{C}$ in $2 \mathrm{~h}$. Good rates are obtained also with the sterically hindered and electronically deactivated 2-bromo-1,3,5-trimethylbenzene. The complex is able to catalyze the exhaustive arylation of 2,3,7,8,12,13,17,18-octabromo-5,10,15-triphenylcorroleCu(III) to yield the corresponding undecaaryl substituted derivative.

(C) 2004 Elsevier Ltd. All rights reserved.
\end{abstract}

The transition metal catalyzed cross-coupling reaction of aryl halides with organoboron compounds (Suzuki reaction) is one of the most efficient methodologies for the formation of new carbon-carbon bonds. ${ }^{1}$ In particular, this reaction provides an effective method for the preparation of biaryls, which are important intermediates in fine chemistry. ${ }^{2}$ A wide variety of palladium ${ }^{1,3,4}$ or nickel ${ }^{5,6}$ derivatives has been used to catalyze the Suzuki reaction. Among the most recent achievements, the development of catalysts able to secure extremely high turnover frequencies ${ }^{3}$ and the use of palladium ${ }^{4}$ and nickel ${ }^{6}$ 'ligand free' catalysts are to be mentioned.

Recently, we have reported that zerovalent palladiumiminophosphine species such as complex $\mathbf{1}$ of Scheme 1 are highly active catalysts in the Stille reaction. ${ }^{7}$ Owing to the similarity of the two reactions, this finding prompted us to investigate the activity of $\mathbf{1}$ in the Suzuki coupling.
Keywords: Suzuki reaction; Iminophosphine complexes; Palladium; Boronic acid; Corroles.

* Corresponding authors. Tel.: +39-041-2348903; fax: +39-041-2348517 (A.S.); tel.: +39-06-72594389; fax: +39-06-72594328 (B.C.); e-mail addresses: scrivanti@unive.it; crociani@stc.uniroma2.it

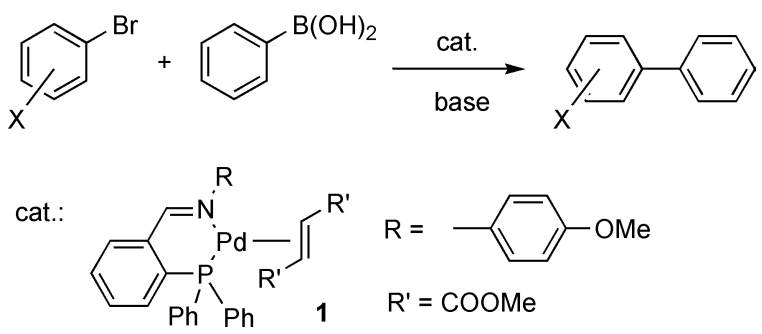

Scheme 1.

In the presence of $\mathbf{1}$, the coupling of 4-bromoacetophenone with phenylboronic acid yields 1-biphenyl-4-ylethanone, the expected coupling product, with almost complete chemoselectivity (see Table 1 for reaction conditions). ${ }^{8}$

At $110^{\circ} \mathrm{C}$, very high reaction rates are obtained: as a matter of fact, using a 4-bromoacetophenone/catalyst molar ratio of $200,000: 1$, a substrate conversion of $82 \%$ is attained in $2 \mathrm{~h}$ (entry 2). Likewise, high reaction rates are obtained with a variety of substrates (Table 1). As it is usually found in the Suzuki coupling, the presence of electron withdrawing groups on the aryl bromide enhances the reaction rate. However, the presence of such activating groups is not essential for the catalyst activity and comparable high reaction rates are obtained also with substrates bearing electron donating substituents 
Table 1. Suzuki coupling reactions catalyzed by complex $\mathbf{1}^{\text {a }}$

\begin{tabular}{|c|c|c|c|c|}
\hline Entry & Aryl bromide & 1 (mmol) & {$[\mathrm{ArBr}] /[1]$} & Yield $^{\mathrm{b}}(\%)$ \\
\hline 1 & 4- $\mathrm{CH}_{3} \mathrm{COC}_{6} \mathrm{H}_{4} \mathrm{Br}$ & $5 \times 10^{-5}$ & 80,000 & 99 \\
\hline 2 & 4- $\mathrm{CH}_{3} \mathrm{COC}_{6} \mathrm{H}_{4} \mathrm{Br}$ & $2 \times 10^{-5}$ & 200,000 & 82 \\
\hline 3 & $4-\mathrm{CF}_{3} \mathrm{C}_{6} \mathrm{H}_{4} \mathrm{Br}$ & $5 \times 10^{-5}$ & 80,000 & 100 \\
\hline 4 & $4-\mathrm{CF}_{3} \mathrm{C}_{6} \mathrm{H}_{4} \mathrm{Br}$ & $2 \times 10^{-5}$ & 200,000 & 95 \\
\hline 5 & $\mathrm{C}_{6} \mathrm{H}_{5} \mathrm{Br}$ & $5 \times 10^{-5}$ & 80,000 & 100 \\
\hline 6 & $\mathrm{C}_{6} \mathrm{H}_{5} \mathrm{Br}$ & $2 \times 10^{-5}$ & 200,000 & 80 \\
\hline 7 & 4- $\mathrm{CH}_{3} \mathrm{C}_{6} \mathrm{H}_{4} \mathrm{Br}$ & $5 \times 10^{-5}$ & 80,000 & 100 \\
\hline 8 & $4-\mathrm{CH}_{3} \mathrm{C}_{6} \mathrm{H}_{4} \mathrm{Br}$ & $2 \times 10^{-5}$ & 200,000 & 76 \\
\hline 9 & 4- $\mathrm{CH}_{3} \mathrm{OC}_{6} \mathrm{H}_{4} \mathrm{Br}$ & $5 \times 10^{-5}$ & 80,000 & 100 \\
\hline 10 & $4-\mathrm{CH}_{3} \mathrm{OC}_{6} \mathrm{H}_{4} \mathrm{Br}$ & $2 \times 10^{-5}$ & 200,000 & 68 \\
\hline 11 & $2-\mathrm{Br}-1,3,5-\left(\mathrm{CH}_{3}\right)_{3} \mathrm{C}_{6} \mathrm{H}_{2}$ & $5 \times 10^{-5}$ & 80,000 & 48 \\
\hline
\end{tabular}

${ }^{\mathrm{a}}$ Reaction conditions. Solvent: toluene $(12 \mathrm{~mL})$; $\mathrm{ArBr}$ : $4.0 \mathrm{mmol}$; base: $\mathrm{K}_{2} \mathrm{CO}_{3}$; base $/ \mathrm{ArBr}=2.0$ (mol/mol); phenylboronic acid: $6.0 \mathrm{mmol}$; [phenylboronic acid] $/[\mathrm{ArBr}]=1.5 ; T: 110^{\circ} \mathrm{C}, t: 2 \mathrm{~h}$.

${ }^{\mathrm{b}}$ By GLC with $n$-undecane as internal standard.

such as methyl or methoxy groups. Excellent activity is also displayed in the coupling of phenylboronic acid with 2-bromo-1,3,5-trimethylbenzene, despite the fact that this substrate is both electronically deactivated and sterically hindered. ${ }^{5 \mathrm{~d}, 9}$

It is worth noting that the catalyst seems air stable and that the experiments can be carried out also under aerobic conditions. ${ }^{10}$

Encouraged by the excellent results obtained with the aryl bromides we have investigated the use of complex $\mathbf{1}$ in the analogous reactions with aryl chlorides. Regrettably, a few preliminary experiments showed that $\mathbf{1}$ is a very poor catalyst for the coupling of 4-chloroacetophenone with phenylboronic acid (entries 1 and 2 of Table 2).

The difference in the catalytic activity towards aryl bromides and aryl chlorides can be exploited to efficiently couple an aryl bromide with a chloro-substituted aryl boronic acid in order to obtain a chloro-substituted biaryl (Scheme 2).

At $110^{\circ} \mathrm{C}$ in toluene, the reaction of 4-bromoacetophenone with 4-chlorophenylboronic acid yields 1-(4-chloro-biphenyl-4-yl)-ethanone ${ }^{6 \mathrm{~b}, 11}$ with almost complete chemoselectivity, the only by-product being 4,4'-chlorobiphenyl (ca. $1 \%$ ) (Table 2). The reaction rate is lower than that obtained with the unsubstituted phenyl-boronic acid, however it is still rather high and a turnover number of ca. 48,000 is obtained in $2 \mathrm{~h}$. Most importantly, a total substrate conversion can be achieved increasing the amount of catalyst and the reaction time.

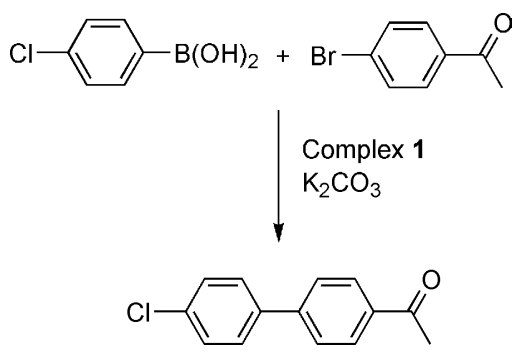

Scheme 2.

As a further step of our investigation, we explored the activity of 1 to synthesize corroles bearing phenyl groups at the $\beta$-positions, following the reaction pathway depicted in Scheme 3. These macrocycles have gained an increasing interest among porphyrin analogs in the last few years, ${ }^{12}$ mainly because of their peculiar coordination chemistry, which can result in potential applications in catalysis and sensor fields. ${ }^{13 \mathrm{~b}}$ From this point of view, fully substituted undecaaryl corroles have not yet been reported in the literature and their preparation can further expand the number of synthetic routes to these macrocycles, opening the way to a facile preparation of a wide range of substituted corroles.

2,3,7,8,12,13,17,18-Octabromo-5,10,15-triphenyl-corrole $\mathrm{Cu}(\mathrm{III})^{14}$ was reacted with 4-chlorophenylboronic acid in toluene at $90^{\circ} \mathrm{C}$ in presence of 1 as catalyst, with a corrole/catalyst ratio of $40,000: 1 .^{15}$ In this case, higher yields were obtained carrying out the reaction under $\mathrm{N}_{2}$ atmosphere. The reaction was complete in $2 \mathrm{~h}$, when no more starting material was observed by TLC. Reaction workup and chromatographic separation over neutral alumina afforded the copper complex of undecasubsti-

Table 2. Reactions of phenylboronic acid with 4-chloroacetophenone and of 4-chlorophenylboronic acid with 4-bromoacetophenone ${ }^{\mathrm{a}}$

\begin{tabular}{|c|c|c|c|c|c|c|}
\hline Entry & Aryl bromide & Boronic acid & 1 (mmol) & {$[\mathrm{ArX}] /[\mathbf{1}]$} & $t(\mathrm{~h})$ & Yield $^{\mathrm{b}}(\%)$ \\
\hline 1 & 4- $\mathrm{CH}_{3} \mathrm{COC}_{6} \mathrm{H}_{4} \mathrm{Cl}$ & $\mathrm{C}_{6} \mathrm{H}_{5} \mathrm{~B}(\mathrm{OH})_{2}$ & $8 \times 10^{-4}$ & 5000 & 24 & 6 \\
\hline 2 & 4- $\mathrm{CH}_{3} \mathrm{COC}_{6} \mathrm{H}_{4} \mathrm{Cl}$ & $\mathrm{C}_{6} \mathrm{H}_{5} \mathrm{~B}(\mathrm{OH})_{2}$ & $2 \times 10^{-2}$ & 200 & 26 & 17 \\
\hline 3 & $4-\mathrm{CH}_{3} \mathrm{COC}_{6} \mathrm{H}_{4} \mathrm{Br}$ & 4- $\mathrm{ClC}_{6} \mathrm{H}_{5} \mathrm{~B}(\mathrm{OH})_{2}$ & $5 \times 10^{-5}$ & 80,000 & 2 & 60 \\
\hline 4 & 4- $\mathrm{CH}_{3} \mathrm{COC}_{6} \mathrm{H}_{4} \mathrm{Br}$ & $4-\mathrm{ClC}_{6} \mathrm{H}_{5} \mathrm{~B}(\mathrm{OH})_{2}$ & $1 \times 10^{-4}$ & 40,000 & 4 & 100 \\
\hline
\end{tabular}

${ }^{\mathrm{a}}$ Reaction conditions. Solvent: toluene $(12 \mathrm{~mL})$; ArX: $4.0 \mathrm{mmol}$; base: $\mathrm{K}_{2} \mathrm{CO}_{3}$; base $/ \mathrm{ArX}=2.0$ (mol/mol); boronic acid: $6.0 \mathrm{mmol}$; [boronic acid]/ $[\mathrm{ArX}]=1.5 ; T=110^{\circ} \mathrm{C}$.

${ }^{\mathrm{b}}$ By GLC with $n$-undecane as internal standard. 


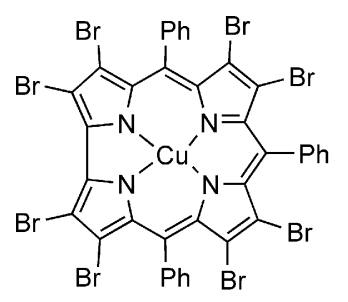

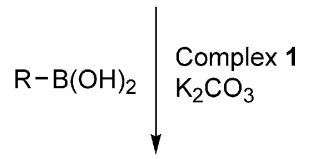

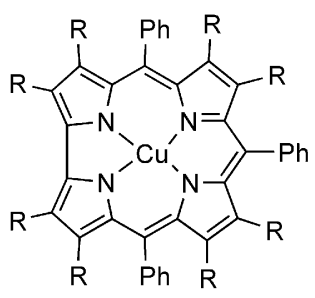<smiles>[R]Cc1ccc(Cl)cc1</smiles>

Scheme 3.

tuted corrole in a reasonable yield $(55 \%)$. It is worth mentioning that $\mathbf{1}$ was able to catalyze the complete substitution of the eight peripheral bromine atoms and no products of partial substitution were observed among the reaction products.

In conclusion, the iminophosphine-palladium(0) complex 1 is a highly efficient catalyst in the coupling of aryl bromides with phenylboronic acids. With an appropriate choice of the reaction conditions, an almost quantitative yield in the coupling products can be obtained. The low activity displayed by the catalyst towards aryl chlorides can be exploited to selectively couple chloro-substituted arylboronic acids with aryl bromides. Further studies aiming to extend this route to the preparation of both free base and other metallocorroles are in progress, and the results will be reported in due course.

\section{References and notes}

1. Recent reviews: (a) Kotha, S.; Lahiri, K.; Kashinath, D. Tetrahedron 2002, 58, 9633; (b) Suzuki, A. J. Organomet. Chem. 2002, 653, 83; (c) Suzuki, A. J. Organomet. Chem. 1999, 576, 147; (d) Suzuki, A. In Metal-Catalyzed Crosscoupling Reactions; Diederich, F., Stang, P. J., Eds.; WileyVCH: Weinheim, 1998; (e) Miyaura, N.; Suzuki, A. Chem. Rev. 1995, 95, 2457.

2. (a) Hassan, J.; Sévignon, M.; Gozzi, C.; Schulz, E.; Lemaire, M. Chem. Rev. 2002, 102, 1359; (b) Stanforth, S. Tetrahedron 1998, 54, 263.

3. (a) Dai, W.-M.; Li, Y.; Zhang, Y.; Lai, K. W.; Wu, J. Tetrahedron Lett. 2004, 45, 1999; (b) Zapf, A.; Jackstell, R.; Rataboul, F.; Riermeier, T.; Monsees, A.; Fuhrmann, C.; Shaikh, N.; Dingerdissen, U.; Beller, M. Chem. Commun. 2004, 38; (c) Navarro, O.; Kelly, R. A., III; Nolan, S. P. J. Am. Chem. Soc. 2003, 125, 16194; (d) Rosa, G. R.; Ebeling, G.; Dupont, J.; Monteiro, A. L. Synthesis 2003, 18, 2894; (e) Bedford, R. B.; Cazin, C. S. J.; Coles, S. J.; Gelbrich, T.; Horton, P. N.; Hursthouse, M. B.; Light,
M. E. Organometallics 2003, 22, 987; (f) Kim, Y. M.; Yu, S. J. Am. Chem. Soc. 2003, 125, 1696; (g) Bedford, R. B.; Hazelwood (née Welch), S. L.; Limmert, M. E. Chem. Commun. 2002, 2610; (h) Schnyder, A.; Indolese, A. F.; Studer, M.; Blaser, H. U. Angew. Chem., Int. Ed. 2002, 41, 3668; (i) Feuerstein, M.; Berthiol, F.; Doucet, H.; Santelli, M. Synlett 2002, 1807; (j) Li, G. Y. J. Org. Chem. 2002, 67, 3643; (k) Alonso, D. A.; Najera, C.; Pacheco, M. C. J. Org. Chem. 2002, 67, 5588; (1) Fürstner, A.; Leitner, A. Synlett 2001, 290.

4. (a) Bedford, R. J.; Blake, M. E.; Butts, C. P.; Holder, D. Chem. Commun. 2003, 466; (b) Deng, Y.; Gong, L.; Mi, A.; Liu, H.; Jiang, Y. Synthesis 2003, 337; (c) Leadbeater, N. E.; Marco, M. Org. Lett. 2002, 4, 2973; (d) Zim, D.; Monteiro, A. L.; Dupont, J. Tetrahedron Lett. 2000, 41, 8199.

5. (a) Zhou, J.; Fu, G. J. Am. Chem. Soc. 2004, 126, 1340; (b) Saito, S.; Oh-tani, S.; Miyaura, N. J. Org. Chem. 1997, 62, 8024; (c) Indolese, A. F. Tetrahedron Lett. 1997, 38, 3513; (d) Griffith, C.; Leadbeater, N. E. Tetrahedron Lett. 2000, 41, 2487; (e) Zim, D.; Lando, V. R.; Dupont, J.; Monteiro, A. L. Org. Lett. 2001, 3, 3049.

6. (a) Lipshutz, B. H.; Sclafani, J. A.; Blomgren, P. A. Tetrahedron 2000, 56, 2139; (b) Zim, D.; Monteiro, A. L. Tetrahedron Lett. 2002, 43, 4009.

7. (a) Scrivanti, A.; Beghetto, V.; Matteoli, U.; Antonaroli, S.; Crociani, B. Tetrahedron 2002, 58, 6881; (b) Crociani, B.; Antonaroli, S.; Matteoli, U.; Scrivanti, A.; Beghetto, V. Dalton Trans. 2003, 2194.

8. Occasionally, traces of biphenyl (never exceeding 1\%) were detected together with the reaction product.

9. (a) Yin, J.; Rainka, P.; Zhang, X.-X.; Buchwald, S. L. J. Am. Chem. Soc. 2003, 124, 1162; (b) Bedford, R. B.; Welch, S. L. Chem. Commun. 2001, 129.

10. Typical Experimental Procedure (entry 2 of Table 1): 4bromoacetophenone $(0.80 \mathrm{~g}, 4.0 \mathrm{mmol})$, phenylboronic acid $(0.73 \mathrm{~g}, 6.0 \mathrm{mmol}), \mathrm{K}_{2} \mathrm{CO}_{3}(1.10 \mathrm{~g}, 8.0 \mathrm{mmol})$, complex $1\left(0.013 \mathrm{mg}, 2.0 \times 10^{-5} \mathrm{mmol}\right)$ and $12 \mathrm{~mL}$ of toluene (freshly distilled from sodium/benzophenone) were introduced into a $50 \mathrm{~mL}$ round bottom flask containing a small magnetic bar. The mixture was heated under stirring at $110^{\circ} \mathrm{C}$ for $2 \mathrm{~h}$ and then cooled to RT. After filtration on Celite the raw reaction mixture was analyzed by GLC using $n$-undecane as internal standard.

11. Huwe, C. M.; Kunzer, H. Tetrahedron Lett. 1999, 40, 683.

12. (a) Paolesse, R. In The Porphyrin Handbook; Kadish, K. M., Smith, K. M., Guilard, R., Eds.; Academic: New York, 2000; Vol. 2, pp 201-231; (b) Erben, C.; Will, S.; Kadish, K. M. In The Porphyrin Handbook; Kadish, K. M., Smith, K. M., Guilard, R., Eds.; Academic: New York, 2000; Vol. 2, pp 233-295; (c) Gryko, D. T. Eur. J. Org. Chem. 2002, 1735.

13. (a) Gross, Z. J. Biol. Inorg. Chem. 2001, 6, 733; (b) Paolesse, R.; Di Natale, C.; Macagnano, A.; Sagone, F.; Boschi, T.; Scarselli, M. A.; Chiaradia, P.; Troitsky, V. I.; Berzina, T. S.; D'Amico, A. Langmuir 1999, 15, 1268.

14. Steene, E.; Dey, A.; Gosh, A. J. Am. Chem. Soc. 2003, 125, 16300 .

15. 2,3,7,8,12,13,17,18-Octa(4-chlorophenyl)-5,10,15-triphenyl-corrolato $\mathrm{Cu}(\mathrm{III}) . \quad 2,3,7,8,12,13,17,18$-Octabromo5,10,15-triphenylcorrolato $\mathrm{Cu}(\mathrm{III})(100 \mathrm{mg}, 0.082 \mathrm{mmol})$ and 4-chlorophenylboronic acid $(205 \mathrm{mg}, 1.31 \mathrm{mmol})$, $\mathrm{K}_{2} \mathrm{CO}_{3}(1.10 \mathrm{~g}, 8.0 \mathrm{mmol}$ ), and $50 \mathrm{~mL}$ of toluene (freshly distilled from sodium/benzophenone) and complex $\mathbf{1}$ $\left(0.0013 \mathrm{mg}, \quad 2.0 \times 10^{-6} \mathrm{mmol}\right)$ were introduced into a $100 \mathrm{~mL}$ Schlenk flask and the solution was degassed by the freeze-pump-thaw method (three cycles) and then heated at $90^{\circ} \mathrm{C}$ under $\mathrm{N}_{2}$ for $2 \mathrm{~h}$. Solvent was then evaporated and the crude product was purified by 
chromatography on neutral alumina (Grade III Brockmann) using $\mathrm{CH}_{2} \mathrm{Cl}_{2}$ as eluant. The product was obtained as red crystals $(66 \mathrm{mg}, 55 \%$ yield) after crystallization from $\mathrm{CH}_{2} \mathrm{Cl}_{2} /$ hexane. $\mathrm{mp}>300^{\circ} \mathrm{C}$. UV-vis: $\lambda_{\max } 438 \mathrm{~nm}$,
558, 642. FAB-MS: $1471(\mathrm{M}+) .{ }^{1} \mathrm{H}$ NMR $\left(\mathrm{CD}_{2} \mathrm{Cl}_{2}\right)$ : $\delta=7.50-6.50(\mathrm{~m})$. Anal. Calcd for $\mathrm{C}_{85} \mathrm{H}_{47} \mathrm{~N}_{4} \mathrm{Cl}_{8} \mathrm{Cu}: \mathrm{C}$, 69.39; H, 3.22; N, 3.81. Found: C, 69.12; H, 3.06; N, 3.69 . 